\title{
Improving the Quality of Student Learning Through the Application of Portfolio-Based Learning
}

\author{
Rifa Nurmilah ${ }^{1, *}$ Yulia Effrisanti ${ }^{2}$ \\ 1,2 STKIP PGRI Jombang, Indonesia \\ *Corresponding author. Email: nurmilah2504@gmail.com
}

\begin{abstract}
This Study aims to describe student activities in the learning process with portfolio-based learning, and to determine student learning outcomes by applying portfolio assessment. portfolio-based learning as a consideration for the progress of the learning process so that students are able to see the progress of each learning outcome. Assessment based on a thorough documentation of student work. The results of this study indicate that student activities show in the active and very active categories seen from the indicators chosen by researchers in portfolio-based learning. This shows the readiness, honesty and confidence of students in learning. Cognitive student learning outcomes also show results in the high category, this shows that students' understanding of the material being studied is good.
\end{abstract}

Keywords: portfolio-based learning, portfolio assessment.

\section{INTRODUCTION}

Along with the development of science and technological advances in the era of the industrial revolution 4.0, the learning paradigm in higher education has undergone many changes, especially in the implementation of the learning process from face-toface to online. Students can study and work at the same time. Because students are adult individuals who can independently learn according to their wishes and goals. Knowledge and experience that have been possessed by students from previous education levels, parents, community, friends, and mass media, so that the student learning process no longer receives information and knowledge but students must be able to receive, analyze, and realize knowledge in the form of concrete activities [1].

One of the tasks of the lecturer in carrying out the tri dharma in the field of teaching in accordance with the competence of professional lecturers is the competence of teaching students who are learning optimally [2]. At this time it is very necessary to prepare learning as well as assessment that can be used as effectively as possible. Where the implementation of learning is carried out during, so that learning can be carried out thoroughly and can control student activities.

Students can understand the material widely through empirical practical learning experiences by linking the concepts of the material studied to a portfolio-based learning model [3]. The portfolio assessment-based learning model is suitable for courses that require student learning output in terms of knowledge, skills and attitudes. This assessment is in the form of an assessment of a collection of student works that are systematically and organized which are taken during the learning process within a certain period of time [4]. Therefore, lecturers should use portfolio learning so that the quality of the process and student learning outcomes is getting better independently and as adult learning.

Gronlund, the portfolio includes a variety of examples of student work depending on the breadth of objectives. What to include, depends on the subject matter and purpose of using the portfolio. These examples of student work provide a basis for consideration of their learning progress and can be communicated to students, parents and other interested parties [3].

The portfolio-based learning model refers to a number of basic principles of learning, namely (1) the principle of active student learning, (2) cooperative learning groups, (3) participatory learning, (4) reactive teaching, (5) joyful learning [5].

Popham, shows the difference in real results between practice, portfolio assessment and standard assessment which is presented in the following table: [6] 
Table 1. Differences in Real Results between Portfolio Assessment and Standard Assessment

\begin{tabular}{|c|c|}
\hline Assessment Portfolio & Standard Assessment \\
\hline $\begin{array}{l}\text { Describe the level of } \\
\text { student achievement in } \\
\text { reading and writing. }\end{array}$ & $\begin{array}{l}\text { Assess students through } \\
\text { writing and reading } \\
\text { assignments within a } \\
\text { limited range that may not } \\
\text { match what students are } \\
\text { doing. }\end{array}$ \\
\hline $\begin{array}{lr}\text { Place students in an } & \text { in } \\
\text { assessment of } & \text { their } \\
\text { progress } & \text { and/or } \\
\text { achievement } & \text { and } \\
\text { demonstrate } & \text { ongoing } \\
\text { learning goals. } & \\
\end{array}$ & $\begin{array}{l}\text { Mechanically scored or } \\
\text { scored by teachers who } \\
\text { have little input. }\end{array}$ \\
\hline $\begin{array}{l}\text { Measuring the ability of } \\
\text { each student while } \\
\text { providing individual } \\
\text { differences } \\
\text { students. }\end{array}$ & $\begin{array}{l}\text { Assess all students in the } \\
\text { same dimension. }\end{array}$ \\
\hline $\begin{array}{l}\text { Describes a collaborative } \\
\text { approach to assessment. }\end{array}$ & $\begin{array}{l}\text { The assessment process is } \\
\text { not collaborative. }\end{array}$ \\
\hline $\begin{array}{l}\text { Have a goal for self- } \\
\text { assessment of students. }\end{array}$ & $\begin{array}{l}\text { Student assessment is not a } \\
\text { goal. }\end{array}$ \\
\hline $\begin{array}{l}\text { Aims to improve work } \\
\text { and abilities. }\end{array}$ & Aim only for ability. \\
\hline $\begin{array}{l}\text { Linking assessment and } \\
\text { teaching to learning. }\end{array}$ & $\begin{array}{l}\text { Separate testing } \\
\text { teaching learning. }\end{array}$ \\
\hline
\end{tabular}

Maesuri, some of the advantages of using portfolios in learning include: 1. Students can describe their own learning and ways to improve it. 2. Students can engage in work at different levels of complexity or support complete work both inside and outside the classroom. 3 . Provide more information about what and how students learn than other students. 4. Become a medium for students, teachers, parents, and external assessors to communicate and convey their expectations about student learning. 5. Provide an accurate picture of the learning program followed by students, in this case helping teachers and external assessors make critical decisions about program effectiveness. 6. Can be used to document student achievement. This means that the assessment given will be more accurate. 7 . Demonstrating students' ability to apply problemsolving knowledge, ability to use scientific language, communicate ideas, ability to reason or analyze. 8. Can improve students' self-evaluation ability. 9. Useful for teachers in identifying the location of students' weaknesses and strengths or providing meaningful diagnostic values for teachers. 10. Feedback given by students will build student understanding. 11. Teachers can detect students' effective variables or monitor students' effective status, including honesty, confidence, perseverance, positive attitude towards learning, and others [7].

In general, a portfolio is a collection of documents of a person, group, institution, organization, company or the like which aims to document the development of a process in achieving the goals that have been set. Portfolios can be used to document student progress. Because they realize the learning process is very important for the success of life, the portfolio can be used by students to see their own progress, especially in terms of development, attitude, skills and expression of something [8].

Based on the background and existing theoretical studies, the researcher can formulate the following problems: how to apply portfolio-based learning in developing the quality of student learning processes and outcomes. And the purpose of this research is to describe the student learning process using portfoliobased learning and to find out student learning outcomes using portfolio assessment.

As for the material or content of the portfolio activities used in this study, several items or indicators were used to measure student activity activities in studying philosophy of education courses. Are as follows: 1. group work 2. group discussion/participant notes 3. presentation of assignments 4 . individual activity records/knowledge. 5. Test. 6. attendance list. 7. negative note

The portfolio assessment used in this study is that student themselves are responsible for compiling their portfolio, namely: formulating learning objectives and actions, doing assignments before the lesson plan, evaluating these assignments, and completing additional assignments. As some are shown here, a lot of assignments and reflections take place during the course, so measure are used. The level of knowledge and skills that exceeds is assessed in the portfolio assessment as a level of knowledge [9].

\section{RESEARCH METHOD}

\subsection{Research Design}

The type of research used is pre-experimental designs. This design does not have a control group to compare with the experimental group [10]. The purpose of this method is to describe the student learning process by applying a portfolio-based learning model and to describe student learning outcomes based on portfolio assessment.

Research design using a One-Shot Case Study, this design involves an exposure of a group to a treatment followed by a measure [10].

Group A $\quad$ X -------------- O

Figure 1. One-Shot Case Study

Description: $\mathrm{X}=$ treatment by applying portfolio-based learning. $\mathrm{O}=$ posttest to measure learning outcomes 


\subsection{Research Sample}

This research sample can be carried out on the same subject. The subjects of the study were students of the 2018 and 2019 class B mathematics education study program STKIP PGRI Jombang in the Philosophy of Education course.

\subsection{Data Collection}

The data collection method used is the observation method and the test method. Observation method is a way of obtaining or collecting data by conducting systematic observations and recordings of a particular object. The observation method is used to collect data about student activities in the learning process. And the test method is a way of obtaining data in the form of a task that must be done by the person or group being tested [11].

\subsection{Research Instruments}

The instrument used to measure student activity is in the form of an observation sheet in which there are several indicators and descriptors of student activity during learning. The learning outcomes test sheet instrument is used to measure student learning outcomes in cognitive aspects.

The data analysis technique used to process research data is to use descriptive and inferential statistics. As for seeing the level of student activity categories and learning outcomes are presented in the following table:

Table 2. Percentage interval of learning activities and learning outcomes

\begin{tabular}{|c|c|c|c|}
\hline No & $\begin{array}{c}\text { Score } \\
\text { interval }\end{array}$ & $\begin{array}{c}\text { Category of } \\
\text { learning } \\
\text { activities }\end{array}$ & $\begin{array}{c}\text { Category of } \\
\text { learning } \\
\text { outcomes }\end{array}$ \\
\hline 1. & $81 \%-100 \%$ & Very active & Very high \\
2. & $71 \%-80 \%$ & Active & High \\
3. & $61 \%-70 \%$ & Active Enough & Medium \\
4. & $51 \%-60 \%$ & $\begin{array}{c}\text { Less Active } \\
\text { Very Less } \\
5 .\end{array}$ & Low \\
& & Active & Very low \\
\hline
\end{tabular}

The categories used in this study for student activities are at least in the moderately active category and student learning outcomes are at least in the moderate category set in the Philosophy of mathematics education course for students of the 2018 and 2019 mathematics education study program in class B.

\subsection{Research Procedure}

This research procedure consists of three main stages, namely: 1 . The preparation stage, including: reviewing phenomena in the field, determining the type of research design and preparing data collection tools. 2. The implementation stage, namely observation, giving tests, and documentation. 3. Analysis stage, which is analyzing all data results from the implementation stage, quantitative data is analyzed using statistics and qualitative data is analyzed descriptively. 4. Writing research reports.

\section{RESULT}

\section{1. student Activity Data}

Data from observations of student activities in the learning process can be shown in the following table:

Table 3. Student Activities in Learning Activities

\begin{tabular}{|c|l|c|c|}
\hline No & Aspects Observed & Percentage & Category \\
\hline 1 & Group work & $92,5 \%$ & Very active \\
\hline 2 & $\begin{array}{l}\text { Group } \\
\text { discussion/participa } \\
\text { nt notes }\end{array}$ & $80,2 \%$ & Active \\
\hline 3 & $\begin{array}{l}\text { Presentation of } \\
\text { assignments }\end{array}$ & $90,8 \%$ & Very active \\
\hline 4 & $\begin{array}{l}\text { Individual activity } \\
\text { log/diary }\end{array}$ & $82,5 \%$ & Active \\
\hline 5 & Test & $100 \%$ & Very active \\
\hline 6 & Attendance list & $98,2 \%$ & Very active \\
\hline 7 & Negative note & $0,25 \%$ & $\begin{array}{c}\text { Very less } \\
\text { active }\end{array}$ \\
\hline
\end{tabular}

Based on the table above and referring to the indicator criteria that have been set, it can be said that every aspect observed during portfolio-based learning activities is in the active and very active category.

\subsection{Learning Outcome Test Data}

Analysis of learning outcomes is used to analyze student learning outcomes data after treatment, namely learning by using a portfolio-based learning model, before conducting data analysis, researchers present the research results that have been obtained. The research data obtained from 41 students from class B is in the form of quantitative data in the form of test scores on the philosophy of mathematics education material.

The research data in question is data on student learning outcomes that have been carried out by researchers in the form of scores (scale 1-100) and can be seen in the following table:

Table 4. Learning Outcome Test Score

\begin{tabular}{|c|l|c|c|}
\hline No & Subyek & Nilai & Keterangan \\
\hline 1 & NS & 75 & Enough \\
\hline 2 & SAK & 82 & High \\
\hline 3 & DSN & 82 & High \\
\hline 4 & LR & 92 & Very high \\
\hline 5 & AANS & 85 & High \\
\hline 6 & NZR & 85 & High \\
\hline
\end{tabular}




\begin{tabular}{|c|l|c|c|}
\hline 7 & WA & 85 & High \\
\hline 8 & P & 82 & High \\
\hline 9 & NSH & 85 & High \\
\hline 10 & SK & 85 & High \\
\hline 11 & VYS & 85 & High \\
\hline 12 & BWCAD & 82 & High \\
\hline 13 & YAY & 85 & High \\
\hline 14 & FBF & 85 & High \\
\hline 15 & NR & 95 & Very high \\
\hline 16 & FNA & 85 & High \\
\hline 17 & IER & 85 & High \\
\hline 18 & AI & 92 & Very high \\
\hline 19 & SSAR & 82 & High \\
\hline 20 & SM & 85 & High \\
\hline 21 & RRA & 85 & High \\
\hline 22 & SNRD & 92 & Very high \\
\hline 23 & SEPN & 82 & High \\
\hline 24 & AAR & 82 & High \\
\hline 25 & IL & 85 & High \\
\hline 26 & VR & 78 & Enough \\
\hline 27 & NNI & 85 & High \\
\hline 28 & RNFP & 82 & High \\
\hline 29 & AR & 75 & Enough \\
\hline 30 & RJN & 82 & High \\
\hline 31 & BAO & 80 & Enough \\
\hline 32 & NAS & 85 & High \\
\hline 33 & FAKA & 85 & High \\
\hline 34 & DFPS & 85 & High \\
\hline 35 & MSFAM & 85 & High \\
\hline 36 & BHR & 82 & High \\
\hline 37 & YIF & 82 & High \\
\hline 38 & MC & 85 & High \\
\hline 39 & SK & 85 & High \\
\hline 40 & ZR & 82 & High \\
\hline 41 & EAR & 82 & High \\
\hline & Sum & $\mathbf{3 . 4 4 5}$ & \\
\hline & Average & $\mathbf{8 4 , 0 2}$ & \\
\hline & & & \\
\hline
\end{tabular}

Based on student learning outcomes data obtained individually, then based on the results of the analysis obtained an average learning outcome of 84.02.

Philosophy of education is one of the general basic courses that must be taken by every student in various study programs, especially students of the mathematics education study program. To improve the quality of education, a new paradigm is needed by a lecturer in the learning process, from teacher-centered learning to innovative and student-centered changes.

There have been many innovative learning models that can improve learning success, one of which is a portfolio-based learning model. The portfolio-based learning model is an innovative learning model that equally invites students to be more active in thinking, communicating and confidently solving a problem independently.

\section{DISCUSSION}

The discussion is based on the results of observing student activities during the learning process and the learning outcomes test method used to determine the average student learning outcomes using a portfoliobased learning model. The portfolio-based learning model has several advantages, including the following.

a. Student learning activities can improve, both cognitively and physically. Students who were originally passive become more active because each student has the same responsibility to solve problems independently and in groups [7].

b. Students' understanding of the material being studied is getting better and can increase learning motivation [9].

c. Effectively train students' discipline to value time to learn. Students can carry out tasks together in discussions as resource persons or participants, so that the learning atmosphere becomes conducive [7]

d. Students can document and reflect directly and indirectly on learning outcomes in a coherent manner during the learning process and their own progress [12].

e. Honesty and self-confidence in participating in learning can be seen from the results of the recap of his diary while attending lectures for educational philosophy courses [7]. Carry out tasks within the allotted time with self-surveillance [13].

The obstacles or weaknesses of this study in the application of the portfolio-based learning model, namely direct control of student activities, still cannot be carried out optimally.

Although this study showed good results, there was no control group was applied as a comparison to the experimental group [9]. So future research should benefit from using control groups to assess whether student learning outcomes are really due to experience with portfolio assessment and portfolio-based learning or are influenced by other factors.

The results of the study can be influenced by the teacher because in learning only one teacher is involved. Especially with regard to the learning approach used, the teacher's effect is for future discovery.

\section{CONCLUSIONS AND SUGGESTIONS}

Based on the results of the research and discussion above, it can be concluded that the application of learning with a portfolio-based learning model in the philosophy of mathematics education course shows the results of student activities in the active and very active categories. Meanwhile, student learning outcomes also showed high average results. This can be used as an 
indicator that individual student learning readiness is good and has good self-confidence.

Suggestions that can be given after the implementation of research and research results;

1. Because learning is carried out during direct control of student activities, there are still problems due to networking and other readiness, so it is necessary to prepare a mature learning plan.

2. Through the application of portfolio-based learning, students can minimize the lack of students in terms of learning by boldly describing their activities in learning so that future researchers can develop portfolio-based learning on other materials and at other levels of education.

\section{AUTHORS' CONTRIBUTIONS}

I would like to thank all those who have contributed to the completion of this research.

\section{ACKNOWLEDGMENTS}

The researchers thank the STKIP PGRI Jombang institution for providing funds to conduct research. With this, researchers can develop their quality as lecturers in the field of research, one of which is the implementation of the tri dharma of lecturers.

\section{REFERENCES}

[1] R, Nurmilah, Meningkatkan Self Directed Learning melalui Problem Based Learning Pada Mahasiswa Prodi Matematika STKIP PGRI Jombang, in: Journal Proceeding, vol. 4.1.2018, pp 312-318.

[2] R. Nurmilah, I Bafadal, E.T. Djatmika, R.W.W, A. Imron, Abd. Qadir Muslim, Developing Professional Lecturers in Higher Education: Case Study in Private Colleges. In: International Journal of Innovation, Creativity and Change. Volume 10, Issue $\quad 11, \quad 2020, \quad$ pp 275-283. https://www.ijicc.net/images/vol10iss11/101120_N urmila_2020_E_R.pdf

[3] Supardi. Model Pembelajaran Portofolio: Strategi Pembelajaran Aktif, Imovatif, Inspiratif, Kreatif dan Menyenangkan. STAIN Salatiga Press, 2013.

[4] R. Setiamiharja, Penilaian Portopolio Dalam Lingkup Pembelajaran Berbasis Kompetensi. In: EduHumaniora| Jurnal Pendidikan Dasar Kampus Cibiru 3.2 .2011, pp 1-20.

[5] Indriyani, Y., Dahlan, D., \& Pinayani, A. (2006). Penerapan model pembelajaran Berbasis Portofolio pada mata pelajaran Ekonomi. Jurnal_Ekop_Vol_1_No_2\%

2C_Juli_2006. pdf.
[6] Trianto. Mendesain Model Pembelajaran InovatifProgresif. Jakarta: Kencana Prenada Media Group, 2009.

[7] S.T. Maesuri, Portofolio Matematika dalam Pembelajaran, 2001

[8] Darling-Hammond, Linda, and Jon Snyder. "Authentic assessment of teaching in context." Teaching and teacher education 16.5-6 (2000):523-545.

https://www.sciencedirect.com/science/article/abs/ pii/S0742051X00000159. PII: S 0742 - 051 X ( $00) 00015-9$

[9] M. Baeten, F. Dochy, K. Struyven. "Students' approaches to learning and assessment preferences in a portfolio-based learning environment." Instructional Science. Instr Sci (2008) 36:359-374. https://www.researchgate.net/publication/2270042 33. DOI 10.1007/s11251-008-9060-y

[10] J.W. Creswell, J.D. Creswell. Research Design: Qualitative, Quantitative, and Mixed Methods Approaches. Fifth Edition. SAGE Publications, Inc.

[11] S. Arikunto. Manajemen Penelitian. Jakarta: Rineka Cipta, 2010.

[12] Anne E. Oosterbaan. Marieke F. van der Schaaf, Liesbeth K.J. Baartman. Karel M. Stokking. "Reflection during portfolio-based conversations." International Journal of Educational Research 49 (2010) 151-160. www.elsevier.com/locate/ijedures doi:10.1016/j.ijer.2011.02.001.

[13] D. Kotsopoulos. "When collaborative is not collaborative: Supporting student learning through self-surveillance". International Journal of Educational Research 49 (2010) 129-140. www.elsevier.com/locate/ijedures doi:10.1016/j.ijer.2010.11.002. 